J. Product. \& Dev., 25(1): 131-147(2020)

\title{
BIOCHEMICAL STUDIES ON THE EFFECT OF SOME BIOFERTELIZERS ON SOYBEAN SHOOTS
}

Atta El-Saber ; R. Saber; Abdel Ghany A. Abdel Ghany and A. Shraf

Agricultural Biochemistry, Soil and Water Science Department, Faculty of Technology \& Development, Zagazig University, Egypt .

E-mail: ataalsaber1@gmail.com.

\section{ABSTRACT}

The field excrement was conducted in the agronomy farm of Gazala, Sharkia, Egypt to study the effect of power mix, citrine and super blue green biofertilizers on some biochemical contents of soybean shoots of (Gizal11 and Crawford) varieties.

The following results were recorded: -

1- All doses of biofertilizers increased dry weight content of shoots to both varieties of soybean. Gizall1 variety recorded relatively greater values than those of Crawford variety.

2- The concentration of chl. $a, \mathrm{chl}$. $b$ and total chl. Of shoots soybean were increased by all treatments while decreased the concentration of carotenoids in shoots only at early stages of Gizal11 variety, but increased of crawford variety at all stages of growth.

3- The percentage of total soluble sugars (reducing and nonreducing) in shoots of crawford variety were greater than those of gizall1 variety and the highest increase of total soluble sugars was obtained by the foliar application of $0.25 \%$ and $0.5 \%$ super blue green biofertilizers.

4- All treatments were increased the concentration of soluble, insoluble and total nitrogen fractions in both varieties of soybean shoots at all stages of growth.

5- All doses of biofertilizers decreased the concentration of $\mathrm{Na}$ in shoots of both varieties of soybean, while they were increased the concentration of $P$ and $K$ at all stages of growth.

6- Fe, Zn and Mn contents were slightly increased by the application of biofertilizers at the early and second stage of growth, while they decreased values at the late stage of shoots growth.

Conclusively, from the current results, it can be noticed that the application of all biofertilizers increased dry weight, photosynthetic pigments (chl. $a$, chl. $b$ and carotenoids), the percentage of total nitrogen were increased either with all doses of biofertilizers in both 
varieties of soybean (Gizal11 and Crawford). the highest increase of total soluble sugars was obtained by the foliar application of $0.25 \%$ and 0.5\% super blue green biofertilizers especially in Gizal11 variety. All micro and macro elements were increased ( $\mathrm{Na}, \mathrm{K}, \mathrm{P}, \mathrm{Fe}$, $\mathrm{Zn}, \mathrm{Mn}$ ) except $\mathrm{Na}$ on all soybean vaterites.

Key words: plant shoot, biofertilizers, soybean varieties, pigments, nitrogen, elements.

\section{INTRODICTION}

Soybean is a globally important oil and protein source of high quality for human consumption, Also, soybean is used as food for animal and is also improved in crop rotation systems Also, throughout history legumes have been used for the supply of food, fodder, fuel and traditional medicine .Biofertilizers are needed small quantities for normal plant growth and development and proceed biological process such as photosynthesis, respiration, synthesis of chlorophyll and simulation of many enzyme.

Mekki and Amal (2005) indicated that application of biofertilizers and organic manure had more plant height and dry weight of soybean plant. On contrast plant height was reduced by adding biofertilizer individual. P, Zn and $\mathrm{Mn}$ elements content were increased in the plants treated by biofertilizers. Getta et al., (2008) reported that, a significant increase of dry weight, nitrogen content and yield of soybean plant, were recorded at biofertilizers application.

Arshad and Nacer (2010) noticed a significant increase of shoots biomass and No. of pods/plant was recorded by the application of biofertilizers on soybean plants. Mahboobeh and Jahanfar (2012) showed that nitrogen content of soybean plant was significantly affected by the foliar application of biofertilizers. Also, the seed number per bods and plant hight were increased by biofertilizers.

Parveen (2013) indicated that the combined use of manure biofertilizer and inorganic fertilizer played a significant role in increasing nitrogen, oil and sugar contents of soybean plant. Manal et al., (2014) obtained results showed that Giza 35 and Crawford varieties of soybean cultivars without using biofertilizers showed a significant increase in dry weight and seed yield. Also, the seeds of plant soybean treated with biofertilizers recorded a significant increase of the uptake of macro and micronutrients as well as nitrogen content of soybean.

Uma and Elakkiga (2014) found that the application of liquid biofertilizers were increased the leave number, high of plant, shoots length 
and biochemical constituents such as chlorophyll, carotenoids, protein and yield. Abdelmohsen (2016) stated that biofertilizers treatments were increased dry weight and nitrogen fractions. Also, he noticed that the effect of different treatments on crude protein percentage followed the same trend as for seed nitrogen percentage.

Raouf (2016) showed that maximum No. of nodules per plant and grain yield were recorded at the application of biofertilizer and mono zinc oxide. The highest dry weight, No. of pods and grains were obtained in application of nano zinc oxide and biofertilizer. Also, an increase of oil and protein content were obtained by applying nano zinc oxide and biofertilizers of soybean.

Therefore, the objectives of this research were to investigation the influence of some biofertilizers on dry weight, photosynthesis pigments, soluble sugars, nitrogen fractions and some macro and micro nutrients of soybean shoots.

\section{MATERIALS AND METHODS}

The field experiment using soybean test crops was conducted during the consecutive growing season of 2018 at the experimental farm of the Faculty of Technology and Development in Ghazala, Zagzig, Sharkia, Egypt. The experiment conducted in the form of a randomized complete block design with three replications of two soybean varities (Giza111 and Crawford) which were brought from seed testing lab Ministry of Agric, Giza, Egypt.

The area of each plot was $3 \mathrm{~m}^{*} 3.5 \mathrm{~m}$ (1/ 400 per feddan). Three folair biofertelizers beside control were used as follow:-

1- Power mix: containing 2\%amino acids, 3\% riboflavin, $0.3 \%$ cytokinine, $0.001 \%$ gibberlic acids, $4.5 \%$ potassiam citrate and $3.5 \%$ micro elements.

2-Citrine: containing 15\%organic acids, $2 \%$ iron grapple, $2 \%$ zinc grapple and $2 \%$ manganese grapple.

3- Super blue green: containing amino acids, vitamins, oxins, cytokinesis, and organic acids.

The foliar biofertilizers were obtained from sigma chemical company and sprayed individually at two concentrations $0.25 \%$ and $0.5 \%$ after 30 days from sowing. Three samples of soybean shoots were taken from each treatment after 45,60 and 75 days from sowing to determine: -

1-Dry weight of soybean shoots.

2-Photosynthesis pigments of shoots.

3-Nitrogen fractions of shoots. 
4-Total soluble (reducing and non-reducing) sugars of shoots.

5-Some macro and micro nutrients of shoots.

\section{METHODS OF ANALYSIS:}

1-Photosynthesis pigments were determined extracted from fresh shoots using acetone (85\%) and determined according to the methods of Wettslein (1957).

2-Total soluble sugars, reducing and non-reducing sugars were determined according to the methods of Mgnetski et al., (1959).

3-Soluble nitrogen was determined according to the methods described by Mengle and Helal (1968).

4-Total nitrogen was determined following the kjeldahel methods as recorded in A.O.A.C. (1970).

5-Phosphours content was determined calorimetrically using ascorbic acid methods as followed by Agiza et al., (1960).

6-Potassium and sodium contents were determined by flame photometer according to Hamdia (2013).

7-Fe, $\mathrm{Mn}$ and $\mathrm{Zn}$ elements were determined according to the standard of procedure described by Block et al., (1965).

\section{Statistical analysis}

The experiment was in a complete randomized block design with 7 treatment and 3 replicates for each treatment.

Results were statistically analyzed using the L.S.D. at probability level of 5\% for comparisons according to Gomez and Gomez (1983).

\section{RESULT AND DISCUSSION}

\section{1-Dry weight of soybean shoots:}

The effect of biofertilizers on dry weight of soybean shoots is presented in Table (1). It is obvious that ,all treatments were increased of dry weight in both varieties (Giza111 and Crawford). This increase not only at early stage of growth (bloom stage),but also at the late stage. This may be due to the accumulation of protein and carbohydrates as results of enhance photosynthesis as well as protein synthesis .The greatest increase of dry weight of shoots was recorded by the foliar application of $0.5 \%$ super blue green $(11.31 \mathrm{gm} / 100 \mathrm{gm})$ to Giza111 variety and $0.25 \%$ power mix (11.21 
Table (1): Effect of some biofertilizers on dry weight of soybean $\operatorname{shoots}(\mathrm{g} / 100 \mathrm{~g})$.

\begin{tabular}{llll|ccc}
\hline \multicolumn{3}{c}{ Treatment } & \multicolumn{3}{c|}{ Giza 111 } & \multicolumn{3}{c}{ crawford } \\
\cline { 2 - 7 } & $\begin{array}{l}\text { Bloom } \\
\text { stage }\end{array}$ & $\begin{array}{l}\text { Mid pod } \\
\text { stage }\end{array}$ & $\begin{array}{l}\text { Late } \\
\text { pod } \\
\text { stage }\end{array}$ & $\begin{array}{l}\text { Bloom } \\
\text { stage }\end{array}$ & $\begin{array}{l}\text { Mid } \\
\text { pod } \\
\text { stage }\end{array}$ & $\begin{array}{l}\text { Late } \\
\text { pod } \\
\text { stage }\end{array}$ \\
\hline Control & $10.22^{\mathrm{c}}$ & $18.99^{\mathrm{d}}$ & $22.19^{\mathrm{c}}$ & $10.88^{\mathrm{c}}$ & $20.10^{\mathrm{d}}$ & $20.16^{\mathrm{c}}$ \\
$\mathbf{0 . 2 5 \% ~ P o w e r ~ m i x ~}$ & $11.01^{\mathrm{b}}$ & $21.51^{\mathrm{a}}$ & $22.89^{\mathrm{b}}$ & $11.21^{\mathrm{a}}$ & $20.33^{\mathrm{c}}$ & $23.67^{\mathrm{a}}$ \\
$\mathbf{0 . 5 \%}$ Power mix & $11.05^{\mathrm{ab}}$ & $21.24^{\mathrm{bc}}$ & $24.33^{\mathrm{a}}$ & $11.03^{\mathrm{ab}}$ & $20.95^{\mathrm{b}}$ & $22.27^{\mathrm{b}}$ \\
$\mathbf{0 . 2 5 \%}$ Citrine & $10.85^{\mathrm{bc}}$ & $21.91^{\mathrm{a}}$ & $24.59^{\mathrm{a}}$ & $11.07^{\mathrm{ab}}$ & $21.13 \mathrm{ab}^{\mathrm{b}}$ & $23.44^{\mathrm{a}}$ \\
$\mathbf{0 . 5 \%}$ Citrine & $10.73^{\mathrm{bc}}$ & $21.21^{\mathrm{bc}}$ & $24.91^{\mathrm{a}}$ & $10.92^{\mathrm{b}}$ & $20.86^{\mathrm{b}}$ & $22.29^{\mathrm{b}}$ \\
$\mathbf{0 . 2 5 \% ~ S u p e r ~ b l u e ~ g r e e n ~}$ & $10.95^{\mathrm{b}}$ & $21.19^{\mathrm{c}}$ & $22.47^{\mathrm{b}}$ & $10.78^{\mathrm{b}}$ & $21.14^{\mathrm{ab}}$ & $22.14^{\mathrm{b}}$ \\
$\mathbf{0 . 5 \%}$ Super blue green & $11.31^{\mathrm{a}}$ & $21.79^{\mathrm{b}}$ & $23.96^{\mathrm{ab}}$ & $10.66^{\mathrm{c}}$ & $21.28^{\mathrm{a}}$ & $22.87^{\mathrm{ab}}$ \\
\hline LSD 0.05 & $\mathbf{3 . 8 1}$ & $\mathbf{0 . 7 2}$ & $\mathbf{1 . 4 4}$ & $\mathbf{1 . 5 1}$ & $\mathbf{1 . 0 2}$ & $\mathbf{1 . 2 2}$ \\
\hline
\end{tabular}

$\mathrm{gm} / 100 \mathrm{gm}$ ) to Crawford variety at the first stage (bloom stage), but the second stage (pod stage), it can be noticed that the foliar application of $0.25 \%$ citrine on Giza111 variety gave the greatest values $(21.91 \mathrm{gm} / 100 \mathrm{gm})$ and $0.5 \%$ super blue green on crawford $(21.28 \mathrm{gm} / 100 \mathrm{gm})$.Also, it can be noticed that Giza111 variety recorded relatively greater dry weight values than crawford variety (Table 1). In this regard, Mekki and Amal (2005) stated a significant increase of shoots biomass, No. pods and dry weight by the application of biofertilizers mixed with organic manure and the same results was obtained by Arshad and Nacer (2010).

\section{2-Photosynthestic pigments in Giza111 shoots: -}

Percentage data in Table (2) showed that, the concentration of photosynthetic pigments of Giza111 variety expressed as $\mathrm{mg} / 100 \mathrm{mg}$ dry weight as affected by photosynthetic $(0.25 \%$ and $0.5 \%)$ from biofertilizers application (power mix, citrine and super blue green).

The data indicated that, at early growth stage (bloom stage) all treatments were increased chl. a, chl. b, and total chl., but decreased the percentage of carotenoids in shoots of Giza111 variety. The greatest increase was recorded by $0.5 \%$ super blue green $(0.78 \mathrm{mg} / \mathrm{gm})$, at the second stage of growth (mid pod stage). It can be noticed that, all doses from biofertilizers were increased the concentration of chl. $a$, chl. $b$ and carotenoids. The highest value of chl.a. was obtained by the application of $0.25 \%$ super blue green $(1.79 \mathrm{mg} / \mathrm{gm})$ and total chl. $(2.86 \mathrm{mg})$.While the third stage of growth (late pod stage) all treatments were increased the content of Chl.A , Chl.B. and carotenoids, where the greatest increase was recorded by the foliar application of $0.5 \%$ citrine $(0.86,0.56,1.42$ and 0.94 $\mathrm{mg} / \mathrm{gm}$ ) to photophysical pigments of shoots, this might be due to the 
assumption that ,biofertilizers which were used retard chlorophyll break dawn via inhibition of chlorophyll enzyme which lead to retarding senescence of shots ,Generally power mix, citrine and super blue green caused an increase in the content of carotenoids which may protect the chlorophyll fractions against the degradation by photosynthesis oxidation process Abdelmohsen (2016).

\section{3-Photosynthesitic pigments in Crawford shoots: -}

The data were tabulated in Table (3). It was evidenced that the application of all treatments from biofertilizers were increased the content of chl. a, chl. b and carotenoids in shoots of crawford variety through the all growth stages. (bloom stage, mid pod stage and late pod stage). The highest values were obtained by citrine $(0.25 \%)$., $(1.16,0.70$ and $0.91 \mathrm{mg} / \mathrm{gm})$ at bloom growth stage, $(1.52,1.78$ and $0.91 \mathrm{mg} / \mathrm{gm})$ at mid pod growth stage and $(0.98,0.89$ and $0.96 \mathrm{mg} / \mathrm{mg})$, at late pod growth stage .This may be due to the high relative increase in the other constituents or to the effect on the rate dehydrogenation of photosynthesis chlorophyll and the activation of the enzymes dealing with processes. A similar result was obtained by Noor et al., (2004) who found that a significant influence of biofertilizers on chl. A. and chl.B. contents of soybean shoots was recorded.

\section{4-Soluble sugars statues of Giza111 shoots:}

It can be generally observed from the results tabulated in Table (4) that there was an increasing effect of biofertilizer treatments on the total soluble sugars (reducing and non-reducing ) in Giza111 variety soybean shoots at all stages of growth .The highest increase of reducing sugars were obtained by spraying $0.5 \%$ super blue green $(0.081,3.01$ and 3.09 $\mathrm{gm} / 100 \mathrm{gm}$ ) at the first stage of growth ,While the application of $0.25 \%$ citrine gave the lowest values of soluble sugars of shoots $(0.031,2.77$ and $2.80 \mathrm{gm} / 100 \mathrm{gm}$ ) as compared with other treatments. This may lead to conclusion that biofertilizers were affected the synthesis of the oligosaccharides. Also, from this table ,the total soluble sugars content in shoots at other growth stages was also increased by foliar application at all doses ,revealing that the increase in some reducing sugar content was not because of biofertilizers activity effect on the synthesis of mono saccharides ,but also on this final distribution of reducing and non-reducing sugar fractions of soybean shoots at the late stage, which reflected on their distribution in seeds as reported by Praveen (2013).Hence it might be concluded that translocation of carbohydrates from shoots to seeds had 


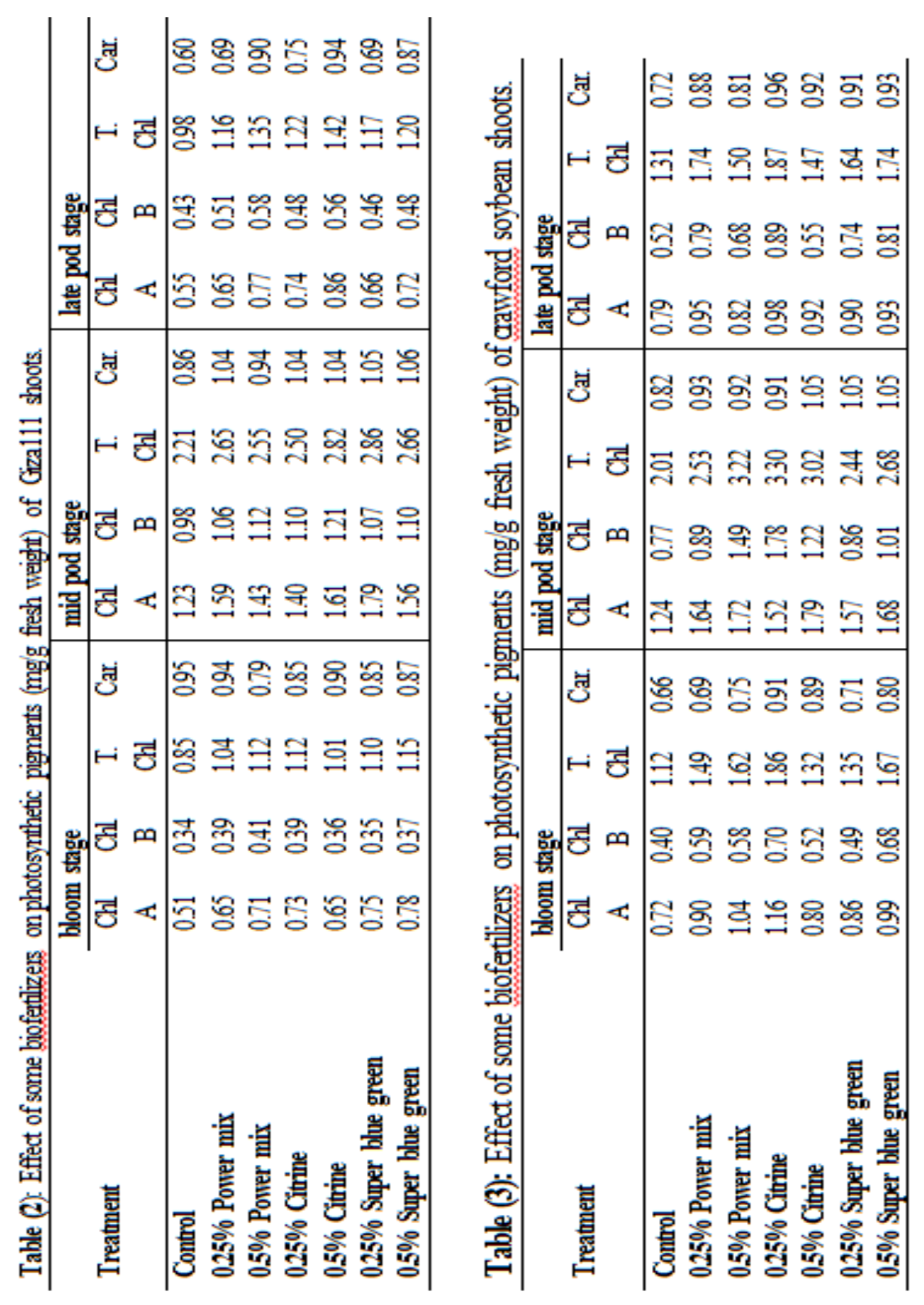


accrued normally without either favorable effect of both biofertilizers used as reported by Getta et al., (2008).

\section{5-Soluble sugars statues of Crawford shoots: -}

Table (5) indicated that the concentration of soluble sugar fractions (reducing and non-reducing)in soybean shoots of Crawford variety were greater than those of Giza111 shoots at all stages of growth for all treatments .Also, it could be noticed that the foliar application of $0.25 \%$ and $0.5 \%$ super blue green gave the highest values of reducing and non-reducing sugars in shoots soybean at the early stage of growth $(0.064,3.91$ and 3.97), $(0.069,3.64$ and 3.71) as compared with control .But the mid pod growth stage, it can be noticed that the highest value of total soluble sugars obtained by $0.5 \%$ citrine $(4.40 \mathrm{mg} / 100 \mathrm{gm})$ while the late pod growth stage the highest value of total soluble sugars was obtained by $0.25 \%$ super blue green. These results of showed that, Table (5), it's worth to illustrate the other treatments have a slight increase effect on reducing, non-reducing and total soluble sugars contents as compared with control. A similar result was obtained by Praveen (2013) and Raouf (2016).

\section{6-Nitrogen fractions statues of Giza111 shoots: -}

The results in Table (6) showed that the foliar application of power mix, citrine and super blue green biofertilizers increased both soluble and insoluble nitrogen fractions in shoots of soybean at all stages of growth except citrine, which caused slight decrease in soluble nitrogen at early growth stage .These results due to the increase in the activity of enzyme synthesis, which take part in nitrogen fixation and protein synthesis Iraj et al., (2012). The greatest increase of total nitrogen was recorded by spraying $0.5 \%$ super blue green at bloom growth stage $(6.65 \mathrm{gm} / 100 \mathrm{~g}), 0.5 \%$ power mix at mid pod growth stage and late pod growth stage (6.98 and 5.64 $\mathrm{gm} / 100 \mathrm{gm})$.Also, it can be noticed that there was, generally, a slight decrease in total nitrogen fraction by the application of $0.5 \%$ citrine as compared with control $(5.72 \mathrm{gm} / 100 \mathrm{gm})$ at bloom growth stage and $(5.83 \mathrm{mg} / 100 \mathrm{gm})$ at mid pod growth stage. These results are in generally agreement with those revealed by Mekki and Amal (2005), and Iraj et al., (2012).The highest sol. /insol shoots resulted by the application of two doses 
of citrine at all growth stages $(35.55 \%, 31.31 \%$ and $3.37 \%)$ and the lowest values of sol./insol ratio were recorded by the application of super blue green biofertilizer $(25.10 \%, 25.83 \%$, and $27.15 \%)$. Also, the ratio between soluble and insoluble nitrogen compounds, is slightly affected by spraying biofertilizers the relative increase in the amount of total nitrogen was noticed when compared with insoluble nitrogen.

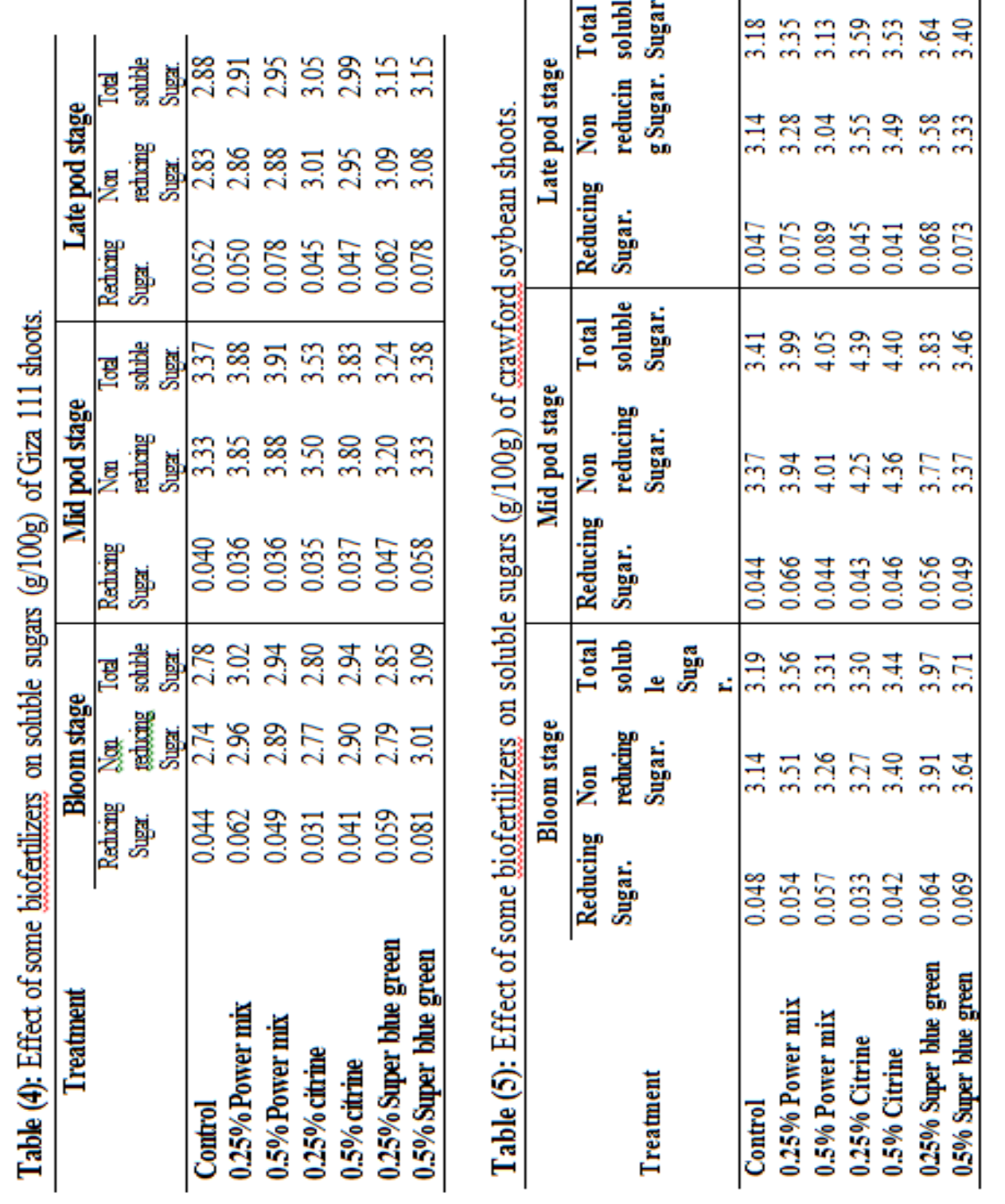




\section{7-Nitrogen fractions statues of Crawford shoots: -}

Data presented in Table (7) showed of shoots that the concentration of nitrogen fraction in soybean shoots as $\mathrm{gm} / 100 \mathrm{gm}$ dry weight as affected by biofertilizers under this investigation. The data indicated that all doses of biofertilizers were increased the concentration of soluble nitrogen fraction of soybean shoots at all stages of growth.

The highest increase resulted by spraying $0.5 \%$ super blue green (1.66 $\mathrm{gm} / 100 \mathrm{gm}$ ) at the first growth stage (bloom stage) as compared with other treatments. Also, the same treatments increased the concentration of insoluble nitrogen fractions, except with citrine treatments at bloom growth stage and mid pod growth stage, which caused a slight decrease of insoluble nitrogen (4.22 and $4.4 \mathrm{gm} / 100 \mathrm{gm})$ at bloom growth stage and (4.54 and 4.48 $\mathrm{gm} / 100 \mathrm{gm}$ ) at mid pod growth stage ,but at late pod growth stage the application of citrine and super blue green caused slight decrease $(4.22$, $4.67,4.59$ and $4.51 \mathrm{gm} / 100 \mathrm{gm})$ as compared with control (4.78 $\mathrm{gm} / 100 \mathrm{gm})$. The highest value of insoluble nitrogen recorded by $0.25 \%$ power mix at bloom growth stage $(4.90 \mathrm{gm} / 100 \mathrm{gm})$ and mid pod growth stage (4.88 $\mathrm{gm} / 100 \mathrm{gm})$,from this data it can be observed that the biofertilizers were caused an increase of the total nitrogen fractions at all stages of growth except when $0.25 \%$ citrine and two doses of super blue green at late pod growth stage (5.70, 5.98 and 5.87\%) as compared with control $(6.08 \%)$. The ratio between soluble and insoluble nitrogen is slightly affected by spraying biofertilizer compared with control. This may be due to the relative an increase of the total nitrogen as compared with insoluble nitrogen . The highest values of sol./ insol. ratio were obtained by $0.5 \%$ citrine at bloom growth stage and mid pod growth stage (36.57 and 34.60 $\%$ ) and $0.25 \%$ citrine at late boom growth stage $(35.07 \%)$. These results are 
in agreement with those obtained by Getta et al (2008) and Manal et al., (2014).

\section{8-Macro elements statues of Giza111 shoots.}

The data presented in Table (8) showed that applied biofertilizers were decreased the concentration of $\mathrm{Na}$ of shoots at all stages of growth as compared with control. It was also observed that the concentrations of $\mathrm{K}$ and $\mathrm{P}$ of shoots were slightly increased at mid pod growth stage $(1.86,2.07$, $1.87,2.07,2.13,1.89$ and $1.92 \mathrm{mg} / 100 \mathrm{gm})$ for $\mathrm{K}$ and $(0.34,0.36,0.35,0.37$, $0.35,0.39$ and $0.35 \mathrm{gm} / 100 \mathrm{gm}$ ) for $\mathrm{P}$ of shoots .It was also noticed from these data that, the application of power mix gave the highest values of $\mathrm{K}$ and $\mathrm{P}$ at late pod growth stage .Similar results were previously reported by Mekki and Amal (2005) and Manal et al., (2014). 
EL-SABER et al.

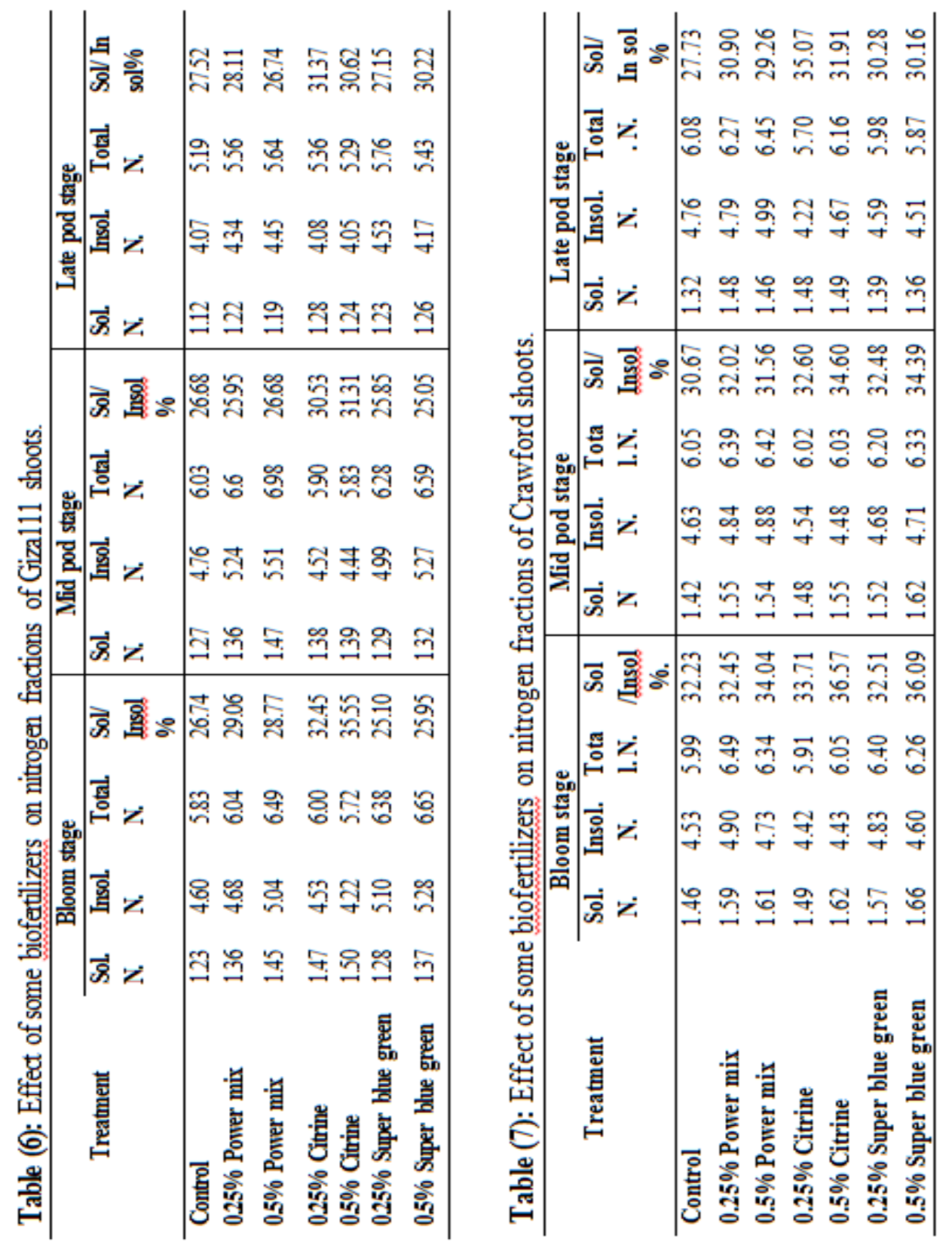


Table (8): Effect of some biofertilizers on macro elements statues ( $\mathrm{g} / 100 \mathrm{~g})$ on Giza111 shoots.

\begin{tabular}{lccc|ccc|ccc}
\hline \multirow{1}{*}{ Treatment } & \multicolumn{3}{c|}{ Bloom stage } & \multicolumn{3}{c|}{ Mid pod stage } & \multicolumn{3}{c}{ Late pod stage } \\
\cline { 2 - 10 } & Na & K & P & Na & K & P & Na & K & P \\
\hline Control & 0.32 & 1.99 & 0.43 & 0.25 & 1.86 & 0.34 & 0.46 & 2.33 & 0.38 \\
$\mathbf{0 . 2 5 \% ~ P o w e r ~ m i x ~}$ & 0.26 & 1.89 & 0.41 & 0.20 & 2.07 & 0.36 & 0.24 & 2.43 & 0.42 \\
$\mathbf{0 . 5 \%}$ Power mix & 0.26 & 1.94 & 0.40 & 0.24 & 1.87 & 0.35 & 0.34 & 2.28 & 0.39 \\
0.25\% Citrine & 0.24 & 1.51 & 0.35 & 0.25 & 2.07 & 0.37 & 0.25 & 2.13 & 0.39 \\
0.5\% Citrine & 0.31 & 1.77 & 0.56 & 0.23 & 2.13 & 0.35 & 0.27 & 2.23 & 0.38 \\
0.25\% Super blue green & 0.25 & 1.87 & 0.36 & 0.21 & 1.89 & 0.39 & 0.23 & 2.38 & 0.37 \\
0.5\% Super blue green & 0.29 & 1.90 & 0.35 & 0.23 & 1.92 & 0.35 & 0.26 & 2.43 & 0.34 \\
\hline
\end{tabular}

\section{9-Macro elements statues of crawford shoots:}

The effect of biofertilizers on the contents of macro elements $(\mathrm{Na}, \mathrm{K}$ and P) in shoots are showed in Table (9). It seems that all treatments were decreased the content of $\mathrm{Na}$ in shoots at all stages of growth ,but the application of $0.25 \%$ and $0.5 \%$ super blue green improved the content of $\mathrm{K}$ at all stages of growth $(2.39,2.53,2.04,1.84,2.64$ and $2.60 \mathrm{gm} / 100 \mathrm{gm})$ as compared with control $(2.22,1.52,2.55, \mathrm{gm} / 100 \mathrm{gm})$ at all stages . Also, most of treatments slightly decreased the content of $\mathrm{P}$ at all stages and the least decreased was recorded by the application of citrine at all stages of growth. These results were in order with those previously reported by Manal et al., (2014).

Table (9): Effect of some biofertilizers on macro elements statues $(\mathrm{g} / 100 \mathrm{~g})$ of Crawford shoots.

\begin{tabular}{lccc|ccc|ccc}
\hline \multirow{2}{*}{ Treatment } & \multicolumn{3}{c|}{ Bloom stage } & \multicolumn{3}{c|}{ Mid pod stage } & \multicolumn{3}{c}{ Late pod stage } \\
\cline { 2 - 10 } & $\mathbf{N a}$ & $\mathbf{K}$ & $\mathbf{P}$ & $\mathbf{N a}$ & $\mathbf{K}$ & $\mathbf{P}$ & Na & $\mathbf{K}$ & $\mathbf{P}$ \\
\hline Control & 0.37 & 2.22 & 0.39 & 0.46 & 1.52 & 0.34 & 0.36 & 2.55 & 0.49 \\
0.25\% Power mix & 0.25 & 1.97 & 0.37 & 0.23 & 1.61 & 0.34 & 0.24 & 2.48 & 0.57 \\
$\mathbf{0 . 5 \%}$ Power mix & 0.23 & 2.13 & 0.39 & 0.26 & 1.56 & 0.37 & 0.23 & 2.53 & 0.42 \\
$\mathbf{0 . 2 5 \%}$ Citrine & 0.36 & 2.18 & 0.35 & 0.27 & 1.58 & 0.32 & 0.23 & 2.25 & 0.34 \\
$\mathbf{0 . 5 \%}$ Citrine & 0.27 & 2.23 & 0.35 & 0.28 & 1.63 & 0.35 & 0.24 & 2.23 & 0.34
\end{tabular}




\begin{tabular}{llll|lll|lll} 
0.25\% Super blue green & 0.25 & 2.38 & 0.38 & 0.29 & 2.04 & 0.39 & 0.22 & 2.64 & 0.35 \\
0.5\% Super blue green & 0.27 & 2.53 & 0.38 & 0.28 & 1.84 & 0.32 & 0.24 & 2.40 & 0.41 \\
\hline
\end{tabular}

\section{0-Micro nutrients statues of Giza111 shoots: -}

Data in Table (10) revealed that the concentration of micro elements such as Fe, $\mathrm{Zn}$, and Mn of shoots were affected by applied biofertilizers (power mix, citrine and super blue green).Fe concentration was increased at bloom growth stage by the foliar treatments as compared with control except that sprayed by Table (10): Effect of some biofertilizers on micro elements statues $(\mathrm{g} / 100 \mathrm{~g})$ of Giza111 shoots.

\begin{tabular}{llll|lll|llll}
\hline \multirow{2}{*}{ Treatment } & \multicolumn{3}{l|}{ Bloom stage } & \multicolumn{3}{l|}{ Mid pod stage } & \multicolumn{3}{l}{ Late pod stage } \\
\cline { 2 - 11 } & Fe & Zn & Mn & Fe & Zn & Mn & Fe & Zn & Mn \\
\hline Control & 0.20 & 0.06 & 0.12 & 0.11 & 0.07 & 0.11 & 0.12 & 0.07 & 0.10 \\
0.25\% Power mix & 0.26 & 0.07 & 0.13 & 0.12 & 0.07 & 0.14 & 0.12 & 0.08 & 0.09 \\
0.5\% Power mix & 0.25 & 0.06 & 0.11 & 0.13 & 0.06 & 0.09 & 0.13 & 0.07 & 0.11 \\
0.25\% Citrine & 0.27 & 0.08 & 0.11 & 0.16 & 0.07 & 0.15 & 0.09 & 0.08 & 0.12 \\
0.5\% Citrine & 0.28 & 0.07 & 0.12 & 0.17 & 0.08 & 0.15 & 0.09 & 0.06 & 0.14 \\
0.25\% Super blue green & 0.13 & 0.08 & 0.11 & 0.12 & 0.09 & 0.13 & 0.09 & 0.09 & 0.11 \\
0.5\% Super blue green & 0.17 & 0.09 & 0.12 & 0.15 & 0.09 & 0.17 & 0.12 & 0.08 & 0.12 \\
\hline
\end{tabular}

all doses of super blue green. The same trend was also found at mid pod stage ,all treatments slightly increased the percentage of Fe, but decreased Fe content of shoots at late pod growth stage .The highest increase of Fe was recorded by the application of $0.5 \%$ citrine at the first growth stage $(0.28 \mathrm{mg} / 100 \mathrm{gm})$ and by $0.25 \%$ and $0.5 \%$ citrine at the second growth stage $(0.16$ and 0.17 $\mathrm{mg} / 100 \mathrm{gm}$ ). This increase of Fe concentration is mainly due to the action of biofertilizer that rendered phosphorus and most micronutrients in the available from Mekki and Amal (2005).

$\mathrm{Zn}$ concentration of shoots soybean slightly increased by all treatments at all stages of growth except some biofertilizers did not have an effect as compared with control. The highest values of $\mathrm{Zn}$ percentage were obtained by the foliar application of super blue green at all stages of growth.

$\mathrm{Mn}$ percentage of soybean shoots was slightly increased at bloom growth stage and mid pod growth stage by the foliar application of $0.25 \%$ power mix only $(0.13$ and $0.14 \mathrm{mg} / 100 \mathrm{gm})$,but the other treatments did not have an effect .Also, at the late pod growth stage it can noticed that there was an slight increase of Mn content of shoots.

\section{1-Micronutrents statues of Crawford shoots: -}

The data presented in Table (11) indicated that micronutrients (Fe, $\mathrm{Zn}$ and $\mathrm{Mn}$ ) under the effect of biofertilizers (power mix, citrine and super blue 
green) Fe concentration was increased at bloom and mid pod growth stages except when foliar application was $0.5 \%$ power mix at mid pod growth stage $(0.10 \mathrm{mg} / 100 \mathrm{gm})$, It can be noticed that , the concentration of Fe at late pod growth stage slightly decrease by all treatments except the application of $0.5 \%$ citrine, which was increased Fe content as compared with control.

From the same table, there was slight effect of biofertilizers on the concentration of $\mathrm{Zn}$ at all stages of growth. Where the application of super blue Table (11): Effect of some biofertilizers on micro elements statues $(\mathrm{g} / 100 \mathrm{~g})$ of Crawford shoots.

\begin{tabular}{lccc|ccc|ccc}
\hline \multirow{2}{*}{ Treatment } & \multicolumn{3}{c|}{ Bloom stage } & \multicolumn{3}{c|}{ Mid pod stage } & \multicolumn{3}{c}{ Late pod stage } \\
\cline { 2 - 10 } & Fe & Zn & Mn & Fe & Zn & Mn & Fe & Zn & Mn \\
\hline Control & 0.10 & 0.07 & 0.12 & 0.15 & 0.08 & 0.11 & 0.09 & 0.08 & 0.07 \\
0.25\% Power mix & 0.11 & 0.06 & 0.14 & 0.14 & 0.08 & 0.11 & 0.08 & 0.09 & 0.06 \\
$\mathbf{0 . 5 \%}$ Power mix & 0.12 & 0.06 & 0.11 & 0.10 & 0.09 & 0.11 & 0.06 & 0.08 & 0.07 \\
0.25\% Citrine & 0.16 & 0.07 & 0.13 & 0.19 & 0.08 & 0.13 & 0.09 & 0.06 & 0.11 \\
$\mathbf{0 . 5 \%}$ Citrine & 0.18 & 0.07 & 0.15 & 0.20 & 0.07 & 0.13 & 0.12 & 0.06 & 0.12 \\
0.25\% Super blue green & 0.14 & 0.06 & 0.11 & 0.20 & 0.09 & 0.13 & 0.07 & 0.10 & 0.08 \\
0.5\% Super blue green & 0.13 & 0.06 & 0.13 & 0.18 & 0.09 & 0.15 & 0.06 & 0.09 & 0.09 \\
\hline
\end{tabular}

green caused a slight decrease of $\mathrm{Zn}$ content at bloom growth stage, but caused a slight increase of the $\mathrm{Zn}$ percentage of shoots at mid pod growth stage.

The concentration of Mn of shoots are showed in Table (11), It found that some treatments did not have an effect on the percentage of Mn at $0.5 \%$ power mix and $0.25 \%$ super blue green at bloom growth stage, $0.25 \%, 0.5 \%$ power mix at mid pod growth stage and $0.5 \%$ power mix at late pod growth. On the other hand, the application of treatments increased the content of $\mathrm{Mn}$ at $0.25 \%$ power mix and $0.5 \%$ citrine was increased $\mathrm{Mn}$ content at bloom growth stage and super blue green treatments at mid pod and late pod growth stages, similar results to those were obtained by Mekki and Amal (2005) and Manal et al., (2014).

Conclusively, from the current results, it can be noticed that the application of all biofertilizers increased dry weight, photosynthetic pigments (chl. a, chl. b and carotenoids), the percentage of total nitrogen were increased either with all doses of biofertilizers in both varieties of soybean (Giza111 and Crawford). the highest increase of total soluble sugars was obtained by the foliar application of $0.25 \%$ and $0.5 \%$ super blue green biofertilizers especially in Giza111 variety. All micro and macro elements were increased ( $\mathrm{Na}, \mathrm{K}, \mathrm{P}, \mathrm{Fe}, \mathrm{Zn}, \mathrm{Mn}$ ), except $\mathrm{Na}$ on all soybean vaterites. 


\section{REFERENCES}

Abdel Mohsen, R.K. (2016). Effect of biofertilizer, Nitrogen and phosphorus on irrigated soybean in Gezira Sudan. ARRN Journal of Agriculture and Biological Science, 11(9):

Agiza, A.H; El-Henidy, M .and Ibrahim, M.E. (1960). The determination of different fractions of phosphorus. Bull. Fac. of Agric. Cairo Univ., 122-127.

A.O.A.C. (1970). Official Methods of Analysis. Association of Official Analysis Chemists. Agriculture Chemists;15, Ed Washington, D.C.S.A.

Arshad.J, and Nacer. M (2010). Growth, Nodulation and yield response of soybean to biofertilizers and organic minerals. P.J. Bol, 42(3):863. 871.

Block, R.J., Durf, E.L. and Zewing, G. (1965). A Manual Of Paper Chromatography And Paper Electrophoresis. $2^{\text {nd }}$ Ed. Academic. Inc. publishers, New York.

Getta, G,Mudenoor. M.G, and Savalgi (2008). Effect of micronutrient supplemented by add rhizobium Biofertilizers on nodulation, dry matter production and yield of soybean. Legume. Res., 31:(1):20.25.

Gomez, K.A. and A.A. Gomez(1983).Statistical Analysis Procedure of Agricultural Research. John Wiley and Sons, New York, pp. 25-30.

Hamdia, A, S.M(2013). The physiological response of wheat to exogenous application of GA3 or IA A. International Journal Of Plant Physiology And Biochemistry,5(4): 58-64.

Iraj, Z, Yousef, S; Gholan, H; Ali, J. and Khosro, M. (2012).Effect of biofertilizers on grain yield and protein content of soybean. African Journal Of Biotechnology, 11 (3): 7028-7037.

Manal, A. Amal, H; Shaban, A. and Abdel Mohsen (2014). Influence of applied biofertilizer on productivity quality and nutrients content of some soybean cultivars under saline soil conditions. J. Soil and Agric. Eng., Mansoura Univ., 5(12) 1647-1666.

Mahboobeh and Jahanfar (2012). Effect of different nitrogen and biofertilizers on growth and yield of Braccianapus. International Journal of Agric. and Crop Science, 4 (8): 478-482.

Mekki, B. B and Amal, G.A. (2005). Growth, yield and seed quality of soybean as affected by organic biofertilizer and yeast application. Research Journal of Agric and Biol.Scince.1(4):320-324.

Mengle, K. and Helal, M. (1986). The effect of varied nitrogen and potassium nutrition on the content of soluble amine compounds in serial parts of outs. Z. P flan Zener anchor. Bodenk,120. (1):12-20. 
Mgnetski, K. P; Tsugarov, Y.A. and Malkov, B.K. (1959). New Methods for Plant and Soil Analysis. Agricultural Academy Press. Manometric techniques. UMB. Rell. Buries Stauffer

Noor, A.; A. Hosseinzadeh and M. Ghafari, (2004). Evaluation of planting date and foliar application of micro elements of sunflower yield component. Proceeding of $3^{\text {rd }}$ National Congress in Efficient Application of Fertilizers in Agriculture, (EAFA'04), Iran, pp: 321-321.

Nacer.B; Ahmold. H.B.; Anne. G.; Hamed, K; Robert. M and Robert.L. Paris (2010). Soybean seed protein, oil, fatty acids and mineral composition as influenced by soybean and corn rotation. Agric. Sci. , 18(3): 102-109.

Raouf. S. S. (2016). Application of biofertilizer and zinc increases yield, nodulation and un saturated fatty acids of soybean. Zem DirbirbysteAgriculture, 103(3): 251-258.

Praveen, K. J. (2013). Effect of Sulphur, zinc and biofertilizers on soybean. An Asian Journal of Agricultural science , 8(2):305-309.

Uma Maheswari N. and T. Elakkiya (2014), Effect of Liquid Biofertilizers on Growth and Yield of Vigna mungo L. Int. J. Pharm. Sci. Rev. Res., 29(2), Article No. 09, Pages: 42-45.

Wettslein, D (1957). Chlorophyll, letaluad der sublnik provision formmech cell. Research, 12:427-433.

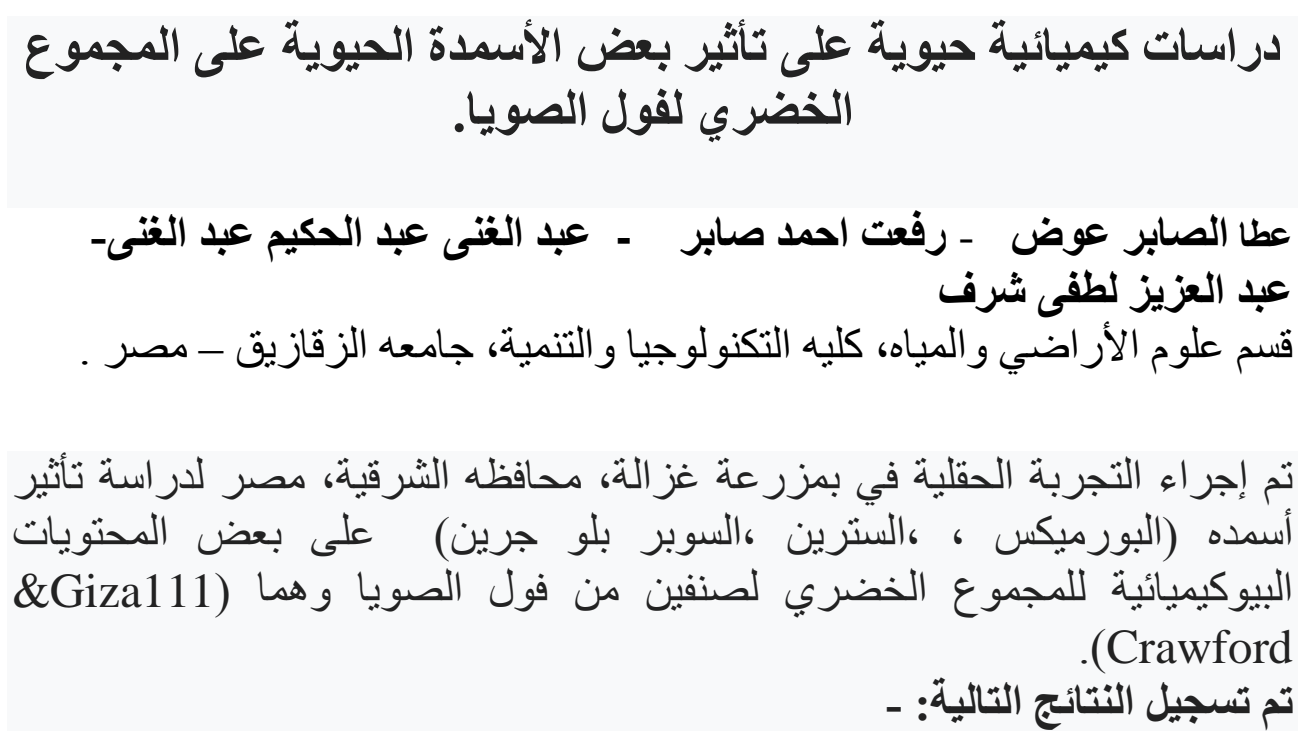




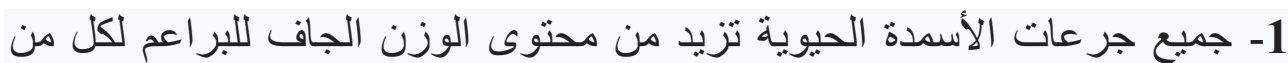

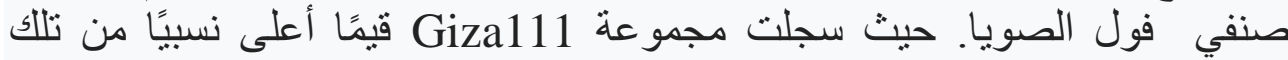

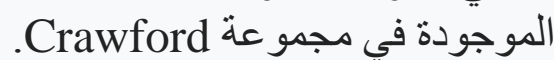

2- تركيز الكلوروفيل (أ)، وكلوروفيل (ب) والكلوروفيل الكلى فيل حدث لهم زيادة في

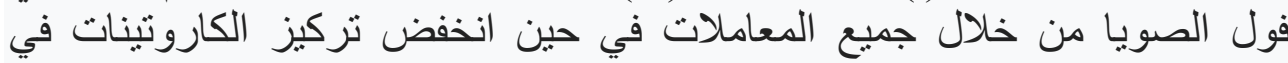

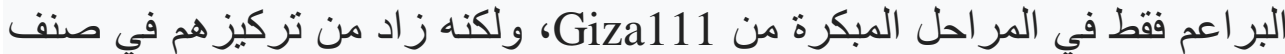
Crawford 3- كانت النسبة المئوية من السكريات القابلة للأوبان الكلية (المختزلة وغير المختزلة)

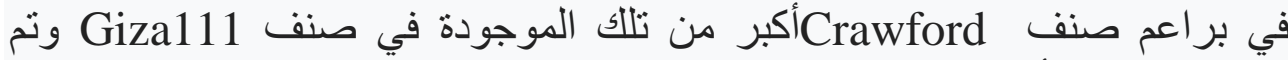

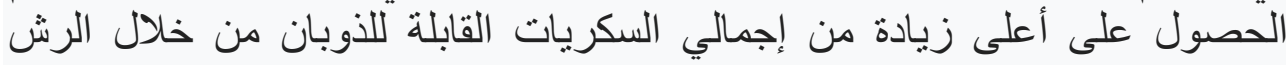

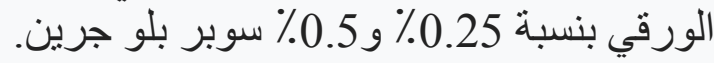

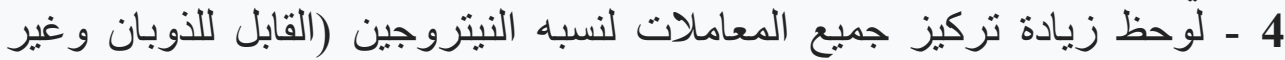
القابلة للذوبان) و الإجمالي في كلا النوعين من بر اعم فول الصويا في جميع مر احل النمو.

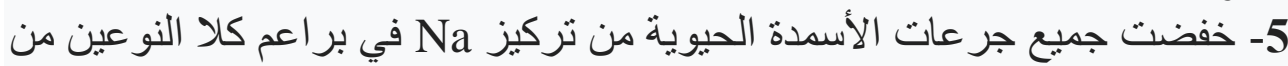

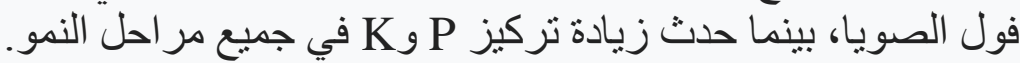
6- تمت زيادة محتوى Mn ،

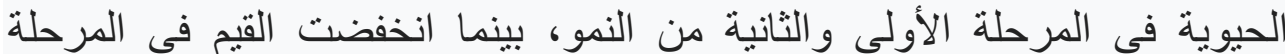

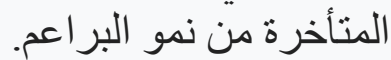
التوصية: من النتائج الحالية، يمكن ملاحظة أن استخدام جميع الأسمدة الحيوية تسبيت

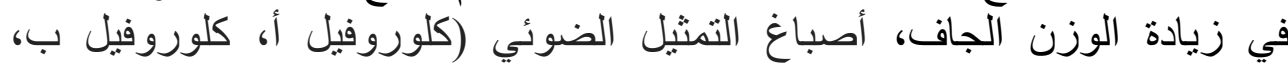

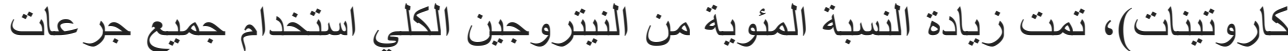

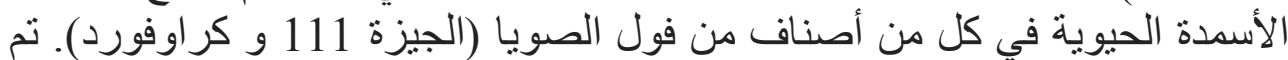

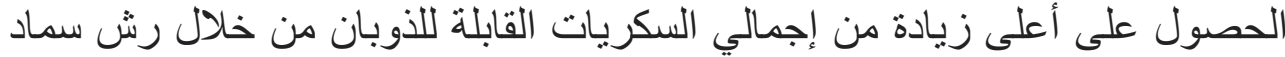

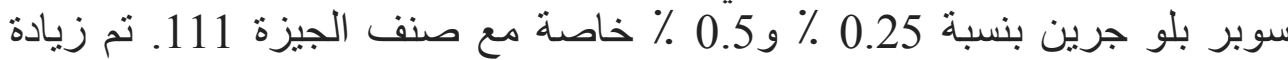

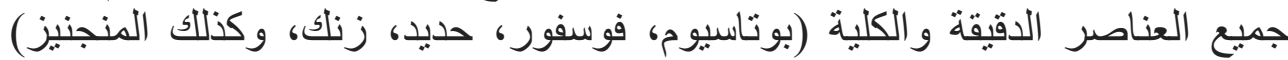

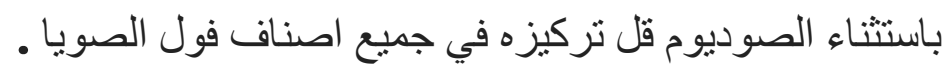

